\title{
Effective Leadership in Democracy
}

\author{
Shiw Balak Prasad \\ University Dept. of Political Science, B.N. Mandal University, Laloo Nagar, Madheprua (Bihar), India \\ Email:shivbalak85@gmail.com
}

How to cite this paper: Prasad, S. B. (2017). Effective Leadership in Democracy. Open Journal of Political Science, 7, 345352.

https://doi.org/10.4236/ojps.2017.73028

Received: April 23, 2017

Accepted: May 30, 2017

Published: June 2, 2017

Copyright $\odot 2017$ by authors and Scientific Research Publishing Inc. This work is licensed under the Creative Commons Attribution International License (CC BY 4.0).

http://creativecommons.org/licenses/by/4.0/

\begin{abstract}
Today most of the democratic countries of the world provide indirect or representative democracy. All men and women are equal before the law of land and there is a provision for free and fair election at periodical intervals. The state has been forbidden to make any discrimination on the ground of religion, race colour, place of residence, sex and the like. The entire authority of leading the government is in the hands of representatives chosen by the people in a democratic manner. Democracy has no meaning if there is no feeling of brotherhood among the people. There must be a feeling among them that they are all the children of the same soil and of the same motherland. Besides, democracy does not mean only political democracy but also includes social and economic democracy. So, ideal and effective leadership in democratic system fulfills the above noted goals.
\end{abstract}

\section{Keywords}

Democracy, Decentralization, Government, Leadership, Power, Voting

\section{Introduction}

Democracy offers a share in the government of the country to every citizen. What touches all should be decided by all. The government of the modern welfare state is adopting such measures as affecting everybody at every state of life. The modern state has come forward to assist the individual from the cradle to the grave. It is therefore essential and desirable that every citizen must be consulted through his representatives as to the policy that should be followed by the national government. Further, it is the grammar of politics, and logic of history that parties must rule alternatively. Democracy alone provides such wide opportunities through which the citizens can have their choices in the determination of the policy of the government. Being the best school for active citizenship, democracy enables a citizen to feel that he has a share in the government. 


\section{Political Power}

Anyway, political power is the result of social facts and remains the eternal possession of the people. The fate of a politician ultimately lies at the ballot box. Being the origin of power, the people know that even the strongest; the Prime Minister cannot have things entirely his own way. Under a Parliamentary type, leadership is glaring because of the virtue of its legislative collaboration. The Parliamentary Executive is continuously and more or less effectively responsible to the legislature for all its policies and acts. Thus the leader is a man of representative opinion possessing foresight, integrity and character.

The role of a leader in public administration is significant. Planning or preparation for any action whatever is the most important administrative function of the leader. Policy-formulation itself is a kind of planning. Its implementation too involves planning. The leader is responsible for the supervision and control of the entire set up. Co-ordination is one of the most important functions of the leader. Conflicts and difference within the organization, if they cannot be harmonized at the lower levels, have to be resolved, in the last resort by the Leader who has the highest authority to do so. The leader has to manage public relations of his organization. Political aspects of these relations have to be carefully dealt with. Then again he has to deal with interest groups, associations of various kinds, the press and the public. From the above discussion of the functions and powers of the leader, it seems, he is nothing short of a dictator in whose hands all authority is concentrated, who can issue whatever orders he likes and exact obedience from his subordinates.

The source of Political power under democracy is primarily the people and secondarily, the legislature which is the representative body of the people. The leader is not merely an instrument for registering and executing the will of the people and the legislature. They want things which should not be done, or may not want what in the best interests of the country should be done. He has, therefore, not merely to follow but also to lead. Indeed, the latter function is more important in the complex conditions of today. There might be hazardous circumstances, as in case of John F. Kennedy, but the leader has to stand the strain of time so as to lead. He must constantly keep his fingers on the pulse of the legislature and the country to watch its trend, react quickly to every unfavorable symptom, and take the necessary steps to counteract it. Even American President though secure in office for his term, finds his administration hampered and discredited unless he is politically alert and influential. Thus political management is the first function of the national leader. Of course, the remedy lies in taking the help of experts but some politicians are temperamentally averse to such help. In such cases, the lay-expert collaboration, which is so fundamental to the successful working of democracy, becomes difficult. The leader can exercise personally the whole of his legal authority no more than the captain of a team can play the whole game by himself. In most cases he has surely to put his seal of approval on the recommendation of his staff of subordinates.

Therefore the first requisite is the strength and balance of personality. 
Strength implies intelligence, firmness of purpose, continuous interest in the work and energy. Balance is rather difficult to define; negatively it may be described as the opposite of lopsidedness. It is the quality that induces people to repose trust in the leader and in his judgment. Irritability, display of undue enthusiasm, a single-tracked mind, vindictiveness, unwillingness to face unpleasantness, or fear of giving offence to any, anyone these are so many deviations from balance of personality, and the more free from them a leader or administrator is, the more he is suited for his work. Experience shows that a successful leader tends to be an extrovert rather an introvert. Again, the quality of leadership has to be measured. It might be the capacity to "lubricate human relationship", "to recreate and retain enthusiasm" or "to make man feel two inches taller in your presence". Great leaders whether in administration or elsewhere are found to possess two traits in common. They identify themselves perfectly with the objective in view. This is the source of the enthusiasm they experience and are able to transmit it to others. They have an attitude of generosity towards those working under them and usually overstate rather than understate the merits and good work of their subordinates. All great leaders have been men of ideas. Another element of leadership is talent for ideas and the power to express them lucidly and eloquently in speech or writing. This quality enables them to find solutions of problems in hand, and to lay down the objectives and goal to which the people are to be led. In India generally, all the third-raters turn to be political leaders: since the intelligentsia is engaged otherwise. Therefore, in many cases, they are dull, inactive, lacking in broad vision and elements of leadership. They believe in heroes and hero-worship. The leader must have administrative ability so as to get things done well and economically by others. The good administrator is a person endowed with the capacity to plan a big project, to create the necessary organization for it to keep that organization working smoothly and efficiently, and to achieve the objective within the limits of the funds, materials, personnel, and the time allotted for the purpose. There is an unending discussion among theorists about the source or basis of administrative ability. Some say it is a natural endowment or inborn quality, and cannot be acquired or made. Others maintain that training and experience can go a long way in creating or, at least improving it.

Now, over and above all this, internal discord, and external invasion have threatened the very edifice of Indian democracy and freedom. Border disputes are nothing new in human history. India's friendship has been the logic of history but there is perhaps no single instance in history where such friendliness has been repaid by unprovoked and treacherous attack. The Chinese invasion has not only endangered the territorial integrity of the country like India but threatens its co-operative and democratic way of life which India has been seeking to evolve ever since the attainment of independence. The basic soundness of India's approach is seen in the spontaneous and generous response of the great democracies in this hour of danger. India's able leadership has been successful in eliciting this unprecedented upsurge of support. It is high time for India to real- 
ize that for safeguarding its hard-won freedom, for progress and prosperity, for increasing the longevity of democracy, something ought to be done.

Emergencies are God-given opportunities for gathering creative strength. Gandhiji's leadership was superb. But his aim was always clearly defined, his lead was unequivocal. In this emergency as things stand the fortunes of the country seem bound up with the personal leadership. In an emergency, what are most needed-above resources, above diplomacy, above party loyalty is a national leadership which evokes faith in the people. With such a faith weak nations have acquired superhuman strength. During the Second Great War the faith which Churchill released, converted a defeated Britain into a victorious one. Great victories both in war and peace are only achieved by faith. But now in India, the young blood is engaged otherwise. The young being revolutionary in nature wants proper channelisation of their energy.

In this hour of crisis, we should not be misguided by the currents and cross currents of propaganda and counter propaganda but stand as potential instruments for future responsibility and stand united with the present leadership.

\section{Rural Leadership}

Panchayati Raj is accepted as a way life to-day in India under the local self Government. An attractive name like "Decentralization" seems to attract popular imagination. The birth of Panchayati Raj has necessitated self-management of the problems of the community, a sense of popular participation and the political education of the villager in the citizenship of his country. The success of Panchayati Raj and the fulfillment of the hopes of people's participation and involvement in the development work in the villages depend largely upon effective local leadership. "No country can hope to achieve good working democracy let alone a Welfare State without a strong and healthy system of local Government" (Robson, 1966). Again, no local Government can remain healthy unless it is liable to change needed to adapt it to change in the human and physical environment.

\section{Background}

Every nation has certain traditions of social and political institutions, ideas and procedures. There has been almost an unbroken tradition of these institutions though with regional and historical variations. But as Hugh Tinker remarks, "The local Government in the present-day India, Pakistan and Burma has inherited but little from indigenous local institutions." However, castism has been playing an important role in Panchatat Raj system in India. Gandhiji wanted village Swaraj by making the individual the architect of his own Government (Hugh, 1954). The achievement of India's independence has cast the ball rolling in favour of political and economic democracy. The sentiment was voiced in the Constituent Assembly, but the Constitution does not seem to have been much influenced by it. In fact, in the beginning stage the Constitution of India does not describe the organization of Panchayati Raj. "One of the longest documents in the world says nothing about panchayati Raj as a form of political organiza- 
tion" (Gandhi, 1942). But Art 40 of the Constitution of India empowers the State to bring about the development of Gram Panchayats (Kothari, 1961). The recommendations of Balwantrai Mehta Committee for Democratic Decentralization of power and responsibility have suddenly given a magical touch to it. It has suddenly acquired political interest and public importance. The accepted goal is to build equal roads from each village to New Delhi. The Mehta Committee recommendations have heralded a new era of revolutionary reform since the British administration in India. The Committee recommended for "Democratic Decentralization" and suggested a three-tier system of administration i.e., Zilla Parishad at the District level, Panchayat Samiti at the Block level and Gram Panchayat at the village level (Indian constitution Article 40). In a big country like India, there is no uniform system of local Government for the whole country. The States have deviated regarding the details of organization. Its greatest merit lies in the contribution it can make to the success of democracy. But Arnold Toynbee while talking of Asian Democracies remarked, "All these Asian peoples wish to run their Governments on democratic lines but a few of them have enough citizens with sufficient experience and public spirit to operate Government of this kind" (Planning Commission of India, 1956). But India is an experiment, and every experiment has its promises as well as hazards. Much will depend upon the type of rural leadership available to man the organization. The organizations are always means to an end, agencies to help achieve what people want. It is the human beings themselves who are the ends. The vital problem is how to make group activity a happy and satisfying experience for people on the basis of a blood stream of friendliness and personal devotion.

\section{Anatomy of Leadership}

"Leadership is the activity of influencing people to co-operate towards some goal which they come to find desirable" (Toynbee, 1962).

The leader must be capable of stimulating and vitalizing others. Consequently, satisfaction and a sense of fulfillment are secured by the followers of the true leader. The leader can arouse popular enthusiasm and local initiative in public service, the lack of which were the chronic maladies of the system. The creation of regional consciousness like "Greater London Consciousness" will gear up the accelerating process of development. Selznik advocates three main premises of leadership (Tead, 1956).

1) Leadership is a kind of work done to meet the needs of a social situation.

2) Leadership is not equivalent to office-holding or high prestige or authority or decision-making.

3) Leadership is dispensable.

The leader being a child of the social process is to focus attention on the social problems and maladies. Institutionalization is said to be a process. An organizational life, of course, does not give up the concern for self-maintenance. It is in this context that we intend to examine the problem of Rural Leadership. The relevant questions in this connection appear to be three only, viz.: 
1) Availability of right type of leaders and the method adopted to secure them;

2) Relationship between official and non-official leadership at all levels, and;

3) Interference by the State level leadership in local leadership, in local affairs and the problem of initiative and flexibility in operations.

\section{Political Socialization}

People get the leaders they deserve. The strains in our social life determine the nature of new leadership. The people are aware of the changing world and they try to make adjustments in the age-old society. Even then, the doctrine of dominant caste is still the guiding principle of rural leadership in India. The caste structure is quite important for the purposes of locating and identifying leadership in the village. This is determined according to the numerical strength, economic structure of the community and leadership pattern are interdependent. Consequent upon diversified production, traditional social leadership has tended to decline. The absence of feudal leadership has further created gulf between the old and the new in the context of contemporary socio-cultural dynamics. Again, caste conflict gives rise to vitiated atmosphere and bitter circumstances. In the faction-ridden village, the dominant faction has the claim to leadership. But in the modern times, the formal political leadership has replaced the institution of traditional leadership. On the support of a group, family and friends, the formal leadership of the Sarpanch or the Chairman is articulated. Normally, it is either due to group domination, economic relationship or money-lending. Behind the screen are persons who can be said to be real leaders. They exercise decisive influence and their authority is based on economic prosperity, personal cleverness and intimate relationship with important individuals outside the locality. The intimate leaders are found in the most rudimentary form in society. Now economic prosperity and education will be formidable rivals of age, caste, and tradition. The burden of future leadership is bound to come upon the young ones. They are supposed to possess enlightened development-oriented outlook, and they have the capacity to gear up development programmes.

A prominent feature of present-day Local Government Organization seems to be the concentration of powers in the hands of the Sarpanch and Chairman. They are said to be called the Chief Ministers of their respective areas in India. But the system concentrates power without corresponding accountability. "India's local bodies at present do not really have an integrated executive at all. There is, on the contrary, a division and dispersal of executive authority" (Selznik, 1957). There is again a unity among the officials and popular elements. Official leadership is supposed to complementary not competitive with the nonofficial leadership. Policy decisions come within the purview of the popular representatives whereas implementation and execution of decisions are under the officers. The idea is to secure active participation of the people and through the devolution of Governmental power and authority. But it is found that the people are not in a position to accept the new projects. Local leadership and initiative were not forthcoming. There was a great estrangement between the officials and 
the common people. There was again absence of tradition of popular co-operation with the administration due to a long history of alien rule in the country. Thus it has made Indian administration negative in mind. The system of Indian local government was of a peculiar colonial pattern as in Malaya and East Africa due to similar circumstances.

The structure of Indian administration was said to be a steel framework since there was no scope for popular participation though the beginnings of Democracy had been made in 1919 by the introduction of Diarchy in India. Secondly, though Indian Constitutional system establishes political democracy, it does not encourage democratic administration. Lord Bryce had compared Indian administration to Plato's Philosopher King. The Scheme of "Democratic Decentralization" has been called neither democratic nor decentralization as evidenced from the Constitution of the local bodies at various levels. All Democracies need intensity of politics and in India, there is a tendency to minimize it. The thinking organs of the Political Parties have to be mobilized in order to reflect public concern about it. The elected representatives do not possess the qualities of comprehensiveness and objectivity about it. As regards decentralization, central controls, supervision and direction were strong in system. A over burdened centre has started spreading the burden more evenly throughout the nation. It enables the large reserves of human energy and ability which might otherwise remain dormant and unused to participate in the administration of Welfare policies. A good State of its health requires freedom from Parliamentary interference. Local authorities must be free from the suicidal consequences of their well-known devotion to the divine right of things as they are.

\section{Conclusion}

Democratic decentralization of power and responsibility to the people's representatives at local levels has resulted in reorientation of the administrative outlook and organization in inter-relationship. But still certain strains in the pattern of adjustments are noticeable. The pattern of administrative organization must be in conformity with the constitution of these bodies and should be complementary to them. Great changes in the history of social organization result generally from the innovative efforts of a few superior individuals. As local government is important for good government, the leader is to inspire the local spirit by the sense of community. The human resources for leadership at the village level are to emerge in due hardly as principals and masters. All the local institutions will assume prominence according to the character, ethical standards, political education, and experience of the people who work it out.

\section{References}

Art. 40 The State Shall Take Steps to Organize Village Panchayats and Endow Them with Such Powers and Authority as May Be Necessary to Enable Them to Function as Units of Self-Government.

Gandhi, M. K. (1942). The Picture of Village Swaraj. The Harijan, 28-7-42. 
Hugh (1954). Thinker-Foundations of Local Government in India, Pakistan and Burma London. 15.

Kothari R. (1961). P.R. Assessment Economic Weekly, May 13, 1961, 75.

Planning Commission of India (1956). Report of the Study Team for the Study of C.D. \& N.E.S. Blocks. Vol. I, 7.

Robson, W. A. (1966). Local Government in the Welfare State. The Political Quarterly, 37, 121-127. https://doi.org/10.1111/j.1467-923x.1966.tb00198.x

Selznick, P. (1957). Leadership in Administration. New York, 22-24.

Tead, O. (1936). The Art of Leadership. Mc-Graw Hill, New York, 20.

Toynbee, A. (1962). Asia Magazine, April, 1962, 3.

Submit or recommend next manuscript to SCIRP and we will provide best service for you:

Accepting pre-submission inquiries through Email, Facebook, LinkedIn, Twitter, etc. A wide selection of journals (inclusive of 9 subjects, more than 200 journals)

Providing 24-hour high-quality service

User-friendly online submission system

Fair and swift peer-review system

Efficient typesetting and proofreading procedure

Display of the result of downloads and visits, as well as the number of cited articles Maximum dissemination of your research work

Submit your manuscript at: http://papersubmission.scirp.org/

Or contact ojps@scirp.org 